\title{
Незабвенный МихСтеп
}

\section{В.К. Грешных}

\begin{abstract}
Статья представляет собой личные воспоминания о выдающемся советском дипломате и ученом-востоковеде Михаиле Степановиче Капице, оставившем заметный след в истории отношений СССР с Китаем, Индией, Пакистаном, Индонезией и другими странами АТР. Будучи автором многочисленных научных трудов, блистательным лектором и необыкновенно харизматичной личностью, Капица ока-зал значительное влияние на формирование советских дипломатиче-ских кадров и востоковедов. М.С. Капица по праву считался как в СССР, так и за рубежом одним из лучших экспертов по проблематике стран ATP.
\end{abstract}

Д верь в темноватую, с одним окном, вместительную комнату на 9-ом этаже державного строения на Смоленке внезапно распахивается и в помещение стремительным шагом врывается могучий, за два метра ростом, высоколобый красавец-мужчина с еле заметной улыбкой на моложавом, невероятно притягательном лице. Все вокруг волшебным образом преображается, светлеет.

- Бездельничаете?!- с подначкой вопрошает он у корпящих над документами сотрудников.

В ответ несется нестройный хор радостных голосов:

- Как можно, Михаил Степанович? До вечера бы управиться с Вашими же поручениями.

По отделу молниеносно разносится: Михстеп опять у китаистов. Беседует с народом «за жизнь». Первый Дальневосточный отдел ( ( ДВО) объединял тогда сплоченную семью специалистов по Китаю, Корее и Монго-лии. «Михстеп»-так трогательно и уважительно называли между собой М.С. Капицу множество людей в огромном здании МИДа и вовне, - настолько внушительны были его известность в дипломатических кругах и популярность среди различных слоев нашего общества в 60-80 гг. ушедшего столетия.

5 ноября 2011 г. Михаилу Степановичу исполнилось бы 90 лет. Это был:

- выдающийся дипломат-востоковед, на пике своей карьеры (1982-1987 гг.)-заместитель министра иностранных дел СССР;

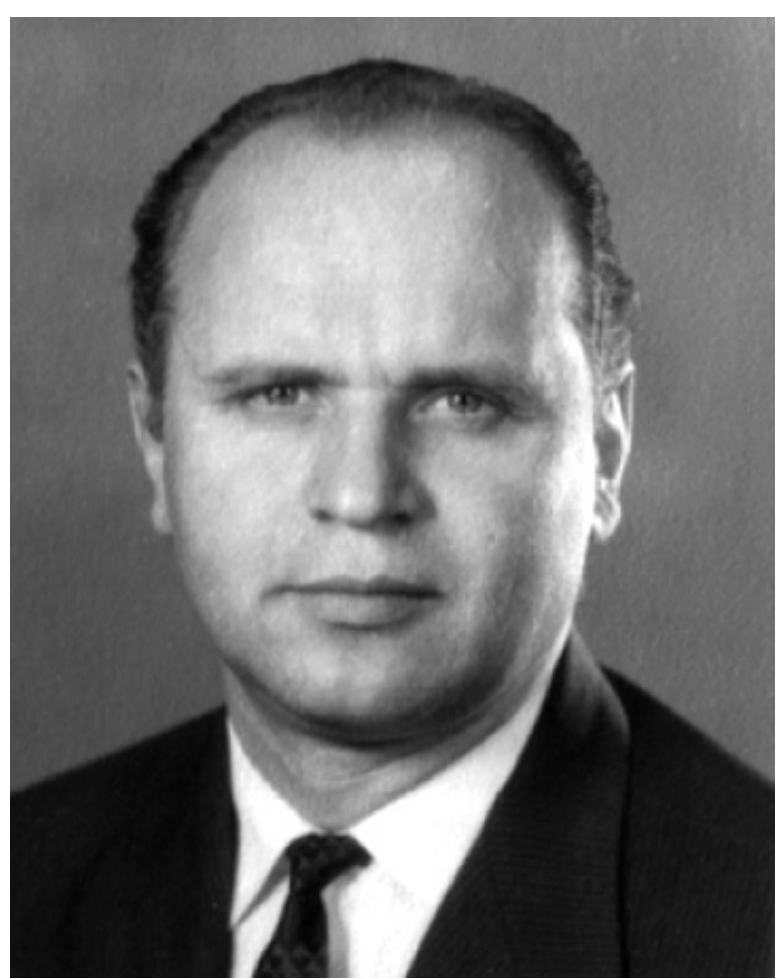

- крупный ученый, член-корреспондент Академии наук СССР, профессор МГУ, автор ряда книг и бесчисленных статей по вопросам внешней политики Китая и обстановки в Азиатско-Тихоокеанском регионе;

- народный депутат Верховного Совета СССР последнего созыва;

Грешных Валерий Константинович - Чрезвычайный и Полномочный Посланник II класса в отставке.

E-mail: vestnik@mgimo.ru 
- председатель Комиссии СССР по делам ЮНЕСКО;

- главный редактор журнала «Азия и Африка сегодня»;

- председатель секции ВАК (Всесоюзной аттестационной комиссии) по вопросам международных отношений;

- директор Института востоковедения АН СССР, РАН (1987-1994 гг.);

- автор 10 монографий и более 100 научных трудов по вопросам советско-китайских связей и истории международных отношений на Дальнем Востоке;

- непревзойденный лектор-международник, на закрытые выступления ко-торого, в условиях бытовавшего в советские времена недостатка информации, с энтузиазмом стекались сотни благодарных слушателей-от сотрудников многочисленных министерств и ведомств до офицеров штаба РВСН и функционеров областного звена.

М.C. Капица по праву принадлежал к элите советской дипломатии, наряду с такими ее знаковыми фигурами, как А.С. Панюшкин, А.Ф. Добрынин, С.В. Червоненко, Ю.М. Воронцов, Г.М. Корниенко, Н.Т. Федоренко и др., поныне здравствующие С.Л. Тихвинский и В.М. Фалин. Поражают масштаб их личностей, органически присущий им дух патриотизма, твердая убежденность в правоте дела, которому они служили.

По крайней мере для двух поколений наших дипломатов-востоковедов М.С. Капица был не просто внимательным и доброжелательным руководителем, но и наставником в необъятном значении этого слова. Именно под его началом стали формироваться профессиональные качества будущих Чрезвычайных и Полномочных пословВ.Я. Воробьева, Е.В. Афанасьева, К.В. Внукова, А.Г. Карлова, А.Н. Рожкова, Л.П. Моисеева, В.Ф. Малышева, ректора Дипломатической Академии МИД РФ Е.П. Бажанова, десятков других опытных специалистов, до сих пор активно действующих на различных участках многогранной дипломатической деятельности.

По неведомым законам природы, на переломных этапах жизни возникают негаданно люди, знакомство с которыми определяющим образом сказывается на судьбе человека, его мировосприятии. Для автора строк таковыми стали встречи с будущим ректором МГИМО Н.И. Лебедевым, рядовым еще аспирантом, нашедшем меня в сборочном цехе одного из куйбышевских авиазаводов и убедившем подать документы для поступления в институт, а также с блестящим преподавателем китайского языка и секретарем парткома МГИМО, уроженцем Харбина Б.С. Исаенко. С началом работы в МИДе-с китаеведом М.С. Капицей, японистом И.Н. Цехоней, американистами, корифеями многосторонней дипломатии А.М. Белоноговым и Ю.М. Воронцовым.

Безмерна моя признательность этим щедро одаренным, воистину неорди-нарным личностям, у которых много перенял и которые неизменно и без колебаний оказывали мне доброжелательную поддержку в сложных ситуациях. Но особо щемящее чувство благодарности испытываю именно к Михаилу Степановичу, старшему товарищу и Учителю, помощником которого мне посчастливилось быть на протяжении длительного периода с трехлетним перерывом на командировку в Японию.

М.С. Капица был своеобычным, неуловимо выпадающим из общего ряда, и вместе с тем, на редкость типичным представителем своего оптимистичного поколения, чей характер оттачивался в предгрозовые тридцатые годы: на фоне успехов в индустриализации страны; триумфов в освоении Арктики; участия наших добровольцев на стороне республиканцев в гражданской войне в Испании; столкновений с японскими милитаристами в районе озера Хасан и на Халхин-Голе. Главными отличительными чертами Михаила Степановича и его сверстников были неуемная тяга к знаниям, чувство локтя и товарищеской взаимовыручки, нестяжания- тот поразительный сплав благоприобретенной интеллигентности и высокой порядочности, который Михстеп пронес в душе через всю свою богатую на сюрпризы и события жизнь.

Уроженец небогатого села Юрковцы (ныне Хмельницкая область Украи-ны), в 1939 г. он протопал босиком сотни верст до Харькова, чтобы попытать удачу при поступлении в университет второй столицы Украины. По рассказам его сокурсника и верного друга И.Н. Цехони, перед тем как войти в город, бу-дущий дипломат тщательно омыл ноги в реке и лишь затем натянул на них единственные сапоги, которые в связке бережно пронес неблизкий путь на своих широченных плечах. И здесь юношу поджидало чувствительное разочарование. По правилам того времени, испытания при поступлении в высшие учебные заведения предписывалось проводить исключительно на русском языке. Капица же, по понятным причинам, на ту пору был с «великим и могучим» далеко не в ладах. Ситуация казалась безвыходной. Выручили, однако, новые приятели. Стайка дотоле в глаза не видевших друг друга девчат и парней с шумом ввалилась в приемную комиссию и после долгих препирательств добилась-таки для Капицы разрешения сдавать экзамены на родном языке. Первый серьезный барьер в жизни был успешно взят. Учился примерный студент по всем предметам на высший балл.

В 1940 г. в университет пришло указание отобрать 7 наиболее ярко заре-комендовавших себя в учебе и общественной работе студентов для зачисления в престижный Институт военных переводчиков. Капица, наряду с Цехоней, попал в число претендентов. Однако в ходе крайне эмоционального и не во всем беспристрастного обсуждения вопроса на комитете комсомола университета один из выступающих высказал сомнение, не повредит ли успешной учебе в Москве чрезмерный, мол, взаимный интерес Михстепа и девушек друг к другу. Кандидатура Капицы на всякий случай большинством голосов была «зару- 
блена». Тогда щупловатый, невысокого роста, но напористый комсорг курса И.Н. Цехоня, по единодушному поручению членов бюро направился «искать правду» в партком. Там, разобравшись в ситуации, настоятельно посоветовали комитету комсомола вернуться к рассмотрению окончательного списка кандидатов на отъезд. На сей раз все прошло гладко. По свидетельству Ивана Николаевича, радости друзей Капицы не было предела. Так, благодаря их бескорыстной помощи и неискоренимому чувству справедливости, было покорено нешуточное по тем временам препятствие. Сколько же их лежало еще впереди!

Обучали в институте на совесть. По рассказам Михаила Степановича, в заведении на Миусской площади подобрался сплоченный коллектив опытных, а, главное, заботливых преподавателей, в большинстве своем еще с основательным дореволюционным образованием. К слову, даже моему поколению несказанно повезло наблюдать в деле и слушать лекции тех же маститых ученых, в частности, профессоров С.Б. Крылова и В.Н. Дурденевского, выпускников соответственно СанктПетербургского и Московского университетов.

С началом Великой Отечественной войны и по мере приближения немец-ко-фашистских войск к Москве было сочтено необходимым эвакуировать кол-лектив института в Среднюю Азию. Позже заведение перебросили ближе к центру страны-в Ставрополь-на-Волге (нынеТольятти), а затем, по мере роста успехов на фронтах, возвратили в столицу. Делалось это поэтапно. По воспоминаниям Цехони, ранней весной 1943 г. отделение слушателей, включая Капицу, отправилось по занесенной снегом Волге в пеший 80-километровый переход до Куйбышева (ныне-Самара). Дался он из-за хронического недоедания и свирепых морозов нелегко. Цехоня, как старший по команде, явился к военному коменданту станции и потребовал, согласно предписанию, офицерский паек для донельзя отощавших курсантов. Комендант, однако, заявил, что, кроме селедки, ничего другого в наличии нет. Цехоня с досадой отреагировал в том смысле, что с таким харчем никакого запаса воды в поезде не хватит, и сгоряча отказался от предложения. Выручила природная находчивость Капицы. Выслушав оправдания сотоварища-неудачника, Михстеп молча выхватил из рук Цехони документы и через полчаса возвратился с двумя мешками селедки на спине. Все замерли в изумлении.

- Ребята, смекайте, дорога лежит по местам, где уже давно не видели соли на столах. Будем менять селедку на картошку, яйца и другие деревенские продукты.

В итоге долгий двенадцатидневный путь до Москвы-вне очереди пропус-кались воинские эшелоны с техникой,-прошел в сравнительной сытости и до-вольстве. А Капица по широте душевной отдал оставшиеся полмешка «деликатеса» уборщицам института, не знавших, куда и усадить парня от свалившегося на их семьи счастья.
Через несколько дней группе было объявлено, что наутро ей надлежит явиться к заместителю наркома по иностранным делам и одновременно НКГБ В.Г. Деканозову. В 10 часов утра в здании на Кузнецком мосту Цехоня представил предвоенному послу СССР в Германии заинтригованную команду. Деканозов заявил, что после разгрома немцев под Сталинградом авторитет страны поднялся на небывалую высоту. Быстрыми темпами расширяются ее международные связи. В этих условиях руководством принято решение, несмотря на все еще сложное положение на фронтах, демобилизовать часть слушателей института, зачислить в НКИД и направить для изучения местных языков и укрепления состава посольств в ряд государств Азии и Ближнего Востока. Взяв паузу, он заключил:

- Цехоне и остальным присваивается ранг атташе, а Вам, Капица,-взглянул грузноватый и малорослый Деканозов на высоченного курсанта,третьего секретаря.

Михаил Степанович позже с юморком делился, как, выйдя от высокого начальства, не мог справиться с нахлынувшим чувством нестерпимой обиды. Ноги вновь сами внесли его, под удивленным взглядом помощника, в кабинет Деканозова. Тот уже начал просматривать кипу документов и с видимым неудовольствием отреагировал на явное нарушение заведенного порядка.

- Что Вам нужно, Капица?- спросил он.

- За что такая несправедливость, товарищ заместитель народного комиссара по иностранным делам?

- А в чем дело? - удивился Деканозов.

- Почему всем присвоено высокое звание атташе, а мне лишь третьего секретаря?

На лице хозяина кабинета промелькнула гримаска недоумения. Хохотнув, он нажал кнопку звонка, вмонтированного в торец стола, и поинтересовался у возникшего в дверях помощника, есть ли в приемной погоны атташе и третьего секретаря. Принесли две пары.

- Ты военный человек и должен разбираться в знаках различия,- обратился Деканозов к новоиспеченному дипломату. Что, на твой взгляд, предпочтительней, несколько небольших звездочек на плечах или одна среднего размера-третьего секретаря? Ступай и работай.

- Ну надо же было так опростоволоситься,посмеивался Михаил Степанович, вспоминая прошлое.

После краткого пребывания в отделе, занимавшегося в НКИД дальнево-сточными проблемами, Цехоня получил назначение в Японию, а Капица был командирован в Китай. С небольшой командой спутников Михаил Степанович прибыл через Ташкент в главный город Синьцзяна-Урумчи. Здесь пришлось надолго задержаться в ожидании самолета из Чунцина, где находилось тогда правительство Чан Кайши и дипломатический корпус: значительная часть территории страны была оккупирована японскими войсками. Времени даром не терял, усердно изучая китайский 
язык. Когда садились в прибывший наконец старенький самолет, по спине, рассказывал Михаил Степанович, пробежал холодок. Дверца изнутри закреплялась обычной веревкой, все части машины в полете угрожающе скрипели и дребезжали. Долетели, к счастью, благополучно.

Приняли в небольшом коллективе посольства радушно. Посол А.С. Па-нюшкин (по совместительству главный резидент советской разведки в Китае: в стране действовали тогда 12 наших резидентур) распорядился направить Капицу в группу, возглавляемую Н.Т. Федоренко. Николай Трофимович приехал в Китай еще ранней зимой 1940 г.

- Он был не на много старше меня,- с чувством вспоминал Михаил Степанович,- но уже был сложившимся специалистом. Слыл признанным знатоком китайского языка, с ним сердечно сотрудничали выдающиеся представители китайской интеллигенции - писатели и поэты Го Можо, Мао Дунь, Лао Шэ, Ся Янь. Человек с изысканными манерами и презентабельной внешностью, переводчик Сталина, а в 50-е годы-произведений Мао Цзэдуна, Федоренко вызывал у Михаила Степановича глубочайшее уважение. С присущей ему душевной прямотой он прилюдно называл будущего посла в Японии, заместителя министра иностранных дел, а затем постпреда СССР при ООН своим учителем, образцом для подражания. А ведь он хорошо был осведомлен о далеко не самом приязненном, в чем-то даже ревнивом отношении А.А. Громыко к этому крупному дипломату и даровитому ученому, его разносторонним познаниям и неповторимому, глубинному ощущению многозвучия общественно-политической, научной и культурной жизни стран Азиатско-Тихоокеанского региона.

Михаилу Степановичу, человеку рабоче-крестьянского происхождения, как с подкупающей искренностью он называл себя, вообще было свойственно открыто демонстрировать свое восхищение талантами и способностями других людей. Его дочь Лариса как-то рассказывала:

- Помню, была еще девочкой, к нам домой приехал из Пекина старенький профессор китайского языка, преподаватель отца еще по чунцинскому периоду. Папа с придыханием говорил о его такте и учености, не знал, куда и подложить подушки на диване. Сопровождал во всех экскурсиях по Москве. Называл не иначе как «сьеншэн». Запомнила на всю жизнь. Понятие «сьеншэн» (учитель) священно в Китае. Дни пребывания профессора в Союзе были настоящим праздником для Капицы.

Михаил Степанович при мне давал временами емкие и разительные по точности характеристики тех, с кем ему приходилось сталкиваться по жизни. Он, сознавая себя как вполне сложившуюся и вызывающую немалый интерес личность, тем не менее не опасаясь быть приниженным или неверно истолкованным, открыто говорил о превосходстве А.Ф. Добрынина в дипломатическом искусстве над коллегами по работе. Несмотря на скрытое дружеское соревнование между ним и С.Л. Тихвинским по части успехов на китаеведческом поприще, Михаил Степанович вслух называл Сергея Леонидовича лучшим переговорщиком среди дипломатов-востоковедов. Исключительно высоко ставил умственные и аналитические способности Л.И. Менделевича, в свое время брошенного Э.А. Шеварднадзе для поисков «нового мышления» на «амбразуру» Управления по внешнеполитическим мероприятиям (УПВМ) и бывшего единственным человеком в МИДе высокого ранга, который писал в своей анкете, что он еврей.

В то же время Капица проявлял поистине отеческую заботу о молодой дипломатической поросли. Не только в МИДе встречаются начальники, которые стараются подольше держать рядом с собой талантливых подчиненных. Капица же никогда не эксплуатировал способности подающих надежды молодых дипломатов и всячески продвигал их на ответственные должности в наших посольствах за рубежом.

Чунцин к моменту приезда Капицы являл собой средоточие во многом разнонаправленных интересов представителей правительства Чан Кайши во главе с правящей партией Гоминьдан, соревнующихся с ними за влияние во внутрикитайских делах коммунистов и руководящих сотрудников аккредито-ванных посольств, в основном союзных держав. Последние пытались, зачастую тщетно, разобраться в хитросплетениях местной политической кухни и одновременно оказать по возможности должное воздействие на противоборствующие стороны в желаемом для их столиц направлении. Дипломатическая и общественная активность, внешняя простота нравов порой зашкаливали. По рассказам Михаила Степановича, в советское посольство, к примеру, в любое время суток могла без предупреждения заехать жена Чан Кайши «почаевничать» с послом. Нередкими гостями посольства были и старавшиеся не привлекать излишнего внимания видные функционеры компартии. Несмотря на бомбежки Чунцина японской авиацией, в дипкорпусе частенько устраивались танцевальные вечера, большим любителем которых был, к слову, Чжоу Эньлай. Именно там познакомился Михаил Степанович с будущим премьером Госсовета КНР. Четверть века спустя это неожиданно сыграет свою добрую роль в ходе встречи в Пекинском аэропорту советской и китайской правительственных делегаций в период серьезного обострения межгосударственных отношений.

В конце декабря 1943 г. в рабочей комнате Капицы раздался звонок. Сек-ретарь просила зайти к послу. Тот встретил гневной филиппикой:

- Вы почему до сих пор не удосужились доложить, что знакомы с Деканозовым? Заместитель наркома прислал мне открытку с поздравлениями по поводу наступающего 1944 г., а в приписке поинтересовался, как трудится Капица...

Михстеп в подробностях поведал о единственной встрече с автором адресованного шефу послания. Александр Семенович расслабился, подобрел. Единственным, но крайне полезным 
результатом разговора для Михаила Степановича явилось то, что посол много чаще стал брать его с собой на важные встречи. Работы значительно прибавилось. По оценке Капицы, именно в чунцинский период были заложены основы его фундаментальных знаний китайской действительности. Панюшкин же через какое-то время был назна-чен послом СССР в США.

Возвращаясь пару раз к фигуре Деканозова, расстрелянного по делу «группы Берия», Михаил Степанович задумчиво рассуждал о превратностях и непредсказуемости бытия. Человек по-разному проявляет себя в предложенных обстоятельствах. Про Деканозова говорили всякое. Объективности ради надо признать, констатировал Михстеп, что, по крайней мере, в судьбе институтских товарищей и его собственной заместитель наркома сыграл памятную и отнюдь не зловредную роль.

По прибытии из командировки на родину, Михаил Степанович, парал-лельно с работой в МИДе, защитил вначале кандидатскую, а затем и докторскую диссертации. Студенты нашего второго курса Восточного факультета - дело было еще до слияния МГИМО и Института внешней торговли - впервые воочию познакомились с Капицей осенью 1957 г. Михаил Степанович с огоньком, даже с неким артистизмом читал лекции по внешней политике Китая, щедро сдабривая речь сочными и малоизвестными фактами периода своего пребывания в соседней стране. На излете семестра настала пора сдачи зачетов. Нестандартный подход Михаила Степановича ко всему, чем ему приходилось заниматься, проявил себя «на полную катушку». По завершении последней лекции для нашей академической группы из 12 человек Капица неожиданно предложил с ходу провести проверку знаний.

- Через час с небольшим,-объяснил он,- надо ехать в Кремль. Никита Сергеевич Хрущев устраивает прием для наших и иностранных дипломатов.

Аудитория с энтузиазмом восприняла эту инициативу. Помнится, мне хватило двух минут, чтобы ответить на вопросы по китайско-советскому договору от 14 февраля 1950 г. Также стремительно и успешно шли дела у друзей. Через 40 минут все было закончено к вящему удовольствию сторон. История окольными путями дошла до парткома института. Назревал скандал. Наступало, однако, время «хрущевской оттепели», и партком ограничился постановкой Капице «на вид» за панибратство со студенческой вольницей, «недопустимое нарушение» воспитательного и учебного процессов.

Конец 1950 - начало 1960-х гг. вообще отличались зримой раскрепощен-ностью общества. МГИМО не составлял исключения. Социальный лифт работал тогда почти без сбоев-в институте учились много ребят и девушек из провинции, демобилизованных солдат-срочников. Отношения между преподавателями и студентами характеризовались высокой степенью взаимного доверия, бескорыстной помощью старших подрастающей смене, поразительной доверительностью во внеурочных контактах и отсутствием жесткой субординации. На память приходит такой полуанекдотичный случай. На подоконнике второго этажа, рядом со спортзалом здания у Крымского моста, где располагался институт, любители шахмат стоя «гоняют блиц». В разгаре зимняя сессия 1962 г. Завсегдатай игры на вылет - Анатолий Федорович Добрынин, заведующий отделом США МИДа, читавший, как и Капица, лекции по избранной тематике, переводит стрелки часов и объявляет:

- Играю последнюю партию, скоро уезжаю на работу в Вашингтон.

- Советником? - интересуется соперник-старшекурсник.

- Бери выше,- глядя на доску, отвечает Добрынин.

- Неужели советником-посланником? - изумляется напарник.

- Почему-то решили назначить послом,- заразительно смеется Анатолий Федорович и после игры прощается со всеми за руку.

Именно столь незаурядные личности, как Капица, Добрынин, их коллеги по цеху, собственным примером и фактами из повседневной практики помогали тогда профессорско-преподавательскому составу института не от случая к случаю, а на постоянной основе формировать у студентов первое реальное представление о грядущих профессиональных обязанностях. Они оказывали внешне малозаметное, но исключительно действенное влияние на становление мировоззрения и ключевых черт характера будущих представителей нашего дипломатического корпуса.

В 1960 г., в возрасте 39 лет, М.С. Капица был назначен послом СССР в Пакистане. За пару лет до этого главой военного режима в стране стал Мухаммед Айюб Хан. В год же приезда Михаила Степановича в Пакистан Айюб Хан формально легитимизировал свое положение во главе государства путем референдума. Благодаря врожденному обаянию, дружелюбию, открытости Капице удалось за короткий срок установить не только насыщенные рабочие, но и доверительные личные отношения как с Айюб Ханом, так и с рядом высокопоставленных представителей пакистанского руководства. В дотоле напряженных советско-пакистанских отношениях обозначились не просто признаки перемен к лучшему, а произошел настоящий прорыв. Приданный им тогда мощный импульс многие годы затем будет оказывать самое позитивное воздействие на состояние двусторонних связей. Капица с теплотой вспоминал время напряженной работы в этой южной стране, с исключительным вниманием продолжал отслеживать события ее внутриполитической и внешнеполитической жизни. Уже будучи заместителем министра иностранных дел, Михаил Степанович, несмотря на высказанное А.А. Громыко недовольство, отказывался посещать мероприятия в посольстве Пакистана в Москве в знак протеста против убийства военными своего добро-го знакомого, четвертого президен- 
та Пакистана (21 декабря 1971 г.-13 августа 1973 г.) Зульфикара Али Бхутто.

Так сложилось, что Михаилу Степановичу пришлось до срока, в 1961 г., вернуться на родину по причинам, в детали которых нет нужды вдаваться. Кстати, помощником Капицы в Пакистане до ухода из МИДа был будущий начальник советской внешней разведки Л.В. Шебаршин. Леонид Владимирович в воспоминаниях о своей работе переводчиком при послах И.Ф. Шпедько, М.С. Капице, А.Е. Нестеренко пишет: «Это были замечательные люди, у которых можно было учиться».

Продолжил Капица свою работу в министерстве с понижением в должно-сти. Однако основательные знания Китая, стран Южной и Юго-Восточной Азии, запредельная работоспособность способствовали быстрому восстановлению былых позиций и дальнейшему служебному росту. С 1966 г. по 1970 г. Михаил Степанович трудился заведующим отделом стран Юго-Восточной Азии МИДа. 1970 г. стал этапным в его служебной деятельности: Капица был назначен заведующим I ДВО, членом коллегии МИД СССР. На этом посту он проработал долгих 12 с половиной лет.

Немаловажной вехой в биографии Михаила Степановича стало его участие в составе нашей делегации во встрече в пекинском аэропорту глав правительств СССР и КНР 11 сентября 1969 г. Перед ее началом Чжоу Эньлай на глазах у А.Н. Косыгина спросил: «А где товарищ Капица?» Состоялся краткий обмен воспоминаниями о былом, что с удовлетворением отметил Председатель Правительства СССР.

- Это важно,-незаметно обратился он к Михаилу Степановичу,-что Чжоу Эньлай неплохо относится к Вам.

К нескрываемой радости Михаила Степановича, был одобрен один из двух вариантов совместного коммюнике, составленные рукой Капицы еще на борту самолета, а именно: лапидарный, что и предугадал Капица в разговоре с А.Н. Косыгиным до начала переговоров. Через какое-то время в I ДВО пришла свежая зарубежная пресса с комментариями к переговорам и снимками. В журнале «Тіме» была опубликована фотография Михстепа, стоящего на верхней площадке трапа правительственного самолета с большим термосом в руках. Молодежь отдела гадала, что же могло бы быть в термосе. Старожилы быстро просветили: Капица вез горячую китайскую еду попотчевать друзей в Москве. Замечательное душевное здоровье и не наигранное внимание к близким маячили за этим феноменальным поступком.

Встреча в Пекине, понятно, не могла снять или существенно ослабить накопившихся противоречий, однако после нее произошло осязаемое смягчение напряженности вдоль всей линии советско-китайской границы. В октябре 1969 г. в Пекине начались переговоры по пограничным вопросам, которые от нас возглавил на первоначальном этапе В.В. Кузнецов. Осенью 1970 г. произошел обмен послами. Это были важные события после столкновений 2 и 15 марта 1969 г. в районе о. Даманский и некоторых других приграничных участках.

Капица был на высоком эмоциональном подъеме, когда стал у руля I ДВО. Трудно сказать, какими соображениями руководствовался Михаил Степанович, назначая меня своим помощником. Думаю, что известную роль могли сыграть чисто ностальгические мотивы: из анкетных данных вытекало, что до прихода в МИД мне довелось в 1962-1964 гг. служить военным переводчиком в Египте. Не без сложностей привыкал к напряженному, ненормированному трудовому дню нового начальника. Михаил Степанович часами безвылазно проводил в кабинете. К этому подталкивала напряженная обстановка в советско-китайских отношениях. Между двумя странами продолжалась острая политическая и пропагандистская полемика. Из этого времени особо врезался в память эпизод, имевший место вскоре после прихода Капицы в отдел.

В один из вечеров в начале июля 1970 г. раздался звонок по телефону правительственной связи. На проводе был первый заместитель министра В.В. Кузнецов, великий труженик, опытный, рассудительный руководитель, многолетний куратор китайского направления деятельности МИД, позже-первый заместитель Председателя Верховного Совета СССР. В кратком разговоре Василий Васильевич поручил Капице срочно набросать проект текста заявления правительства по положению на советско-китайской границе. Одновременно предупредил, что А.А. Громыко будет у себя вплоть до завершения работы над документом. Меня поразила молниеносная реакция Михаила Степановича. Призвав писать разборчивее, шеф тут же начал, без обращения к источникам, но с периодическими паузами, членораздельную задиктовку материала. Через час с небольшим Капица был готов предстать перед Кузнецовым.

- Пойдем со мной,- сказал он,-машинисток я пораньше отпустил по до-мам, проверишь, как справятся девчата Василия Васильевича.

В секретариате на седьмом этаже нас уже ждали. Сработали опытные сотрудницы аппарата Кузнецова безупречно. Внимательно просмотрев набранный текст, Михаил Степанович завизировал его и, неожиданно подхватив меня под локоть, буквально втолкнул в кабинет второго лица мини-стерства.

Кузнецов вышел из-за стола и мягко пожал обоим руку. Михаил Степанович оправдал мое присутствие тем, что я недавно вернулся из Пекина и мог бы со своими неостывшими впечатлениями при случае оказаться полезным по ходу дела. Кузнецов кивнул и начал вслух, абзац за абзацем, медленно читать проект заявления, скрупулезно взвешивая каждое его положение. При минимуме поправок текст был в итоге согласован, к нескрываемому удовлетворению Капицы. Перед расставанием между старшими по званию 
возник небольшой диспут относительно вероятной расстановки сил в китайском руководстве в контексте полыхавшей «культурной революции». Мнения сошлись не во всем. Поощрительно улыбаясь, Кузнецов вдруг обратился ко мне с вопросом: чью точку зрения я предпочел бы поддержать? По наивности прямолинейно ляпнул, что его, В.В. Кузнецова. Тут же схлопотал под столом ботинком Михстепа чувствительный удар по ноге. Разумеется, страшно расстроился в ожидании заслуженной и, казалось, неотвратимой взбучки. И не угадал. Выйдя из кабинета Кузнецова, Михаил Степанович лишь отрывисто бросил:

- Теперь с бумагой к Громыко.

В приемной, окинув нас полным значения взглядом, хозяйничал старший помощник министра В.Г. Макаров.

- Василий,- обратился к Макарову Капица, указывая на меня глазами,- он недавно из Пекина.

Незатейливая фраза на фоне неприятных событий в двусторонних отношениях магическим образом открывала в тот момент двери, очевидно, всех сановных кабинетов. Макаров посторонился и вслед за Капицей пропустил непонятно откуда взявшегося незнакомца к министру. Громыко обменялся с Михаилом Степановичем рукопожатием, в мою сторону после-довал сдержанный кивок.

Предложив нам присесть, министр размеренным движением отложил в сторону единственную на столе папку с шифротелеграммами и, полюбовавшись несколько мгновений солнечным вечером за окном, принялся неспешно изучать содержание документа. Привнеся в текст заключительные мазки, он перевел внимательный взор на Капицу и обратился к ситуации в районе островов Большой Уссурийский и Тарабаров. В период обмеления пограничной протоки Казакевичева возникали проблемы с проходом китайских гражданских судов по Амуру мимо Хабаровска (позднее договоренность на сей счет была оформлена в 1977 г.).

- Меня,-начал Громыко,-серьезно беспокоит обстановка здесь. Вряд ли стоит закрывать глаза на то, что, по крайней мере, в какой-то части доводов китайской стороны присутствует своя, внешне достаточно убедительная, логика. У меня, признаться, нет сложившегося мнения по этому вопросу. Не знаю, как и быть. .

Капица заявил, что эта тема является одной из самых болезненных в практике повседневных взаимоотношений.

- Пристально отслеживайте обстановку, при необходимости докладывай-те,- напутствовал министр Капицу.

Этот разговор произвел на меня неизгладимое впечатление и послужил запоминающимся уроком профессионализма и высочайшей ответственности на долгие годы. Министр в присутствии начинающего сотрудника не постеснялся признать отсутствие на тот день представления о дальнейших действиях, пер-спективных способах обоюдоприемлемого выхода из затруднительной ситуации.
Подкупило и внешне спокойное, полное достоинства поведение Михаила Степановича в разговоре с министром.

Анализируя со всех сторон события того вечера, много позже пришел к заключению, что Михаил Степанович, как опытный руководитель, приказал следовать за собой в кабинеты высокого начальства, по-видимому, в расчете на то, что их хозяева запомнят физиономию сопровождающего на будущее. Дело в том, что минул уже год после моего возвращения из Китая. Это была еще одна завидная, свойственная далеко не каждому, удивительная грань его непостижимо широкого, постоянно нацеленного на добро характера.

В классической связке начальник-подчиненный многое в работе зависит от человеческих свойств и уровня профессионализма руководителя, притом не без постоянного и вполне естественного внутреннего напряжения младшего по иерархии. По моим скромным наблюдениям, отношения между В.В. Кузнецо-вым и Михаилом Степановичем носили ровный, деловой характер с элементами скрытой взаимной приязни. Практически любой контакт с Кузнецовым - будь то по телефону или в кабинете непосредственного шефа - вызывали у Капицы очередной прилив творческой энергии и заразительного служебного рвения. Приятно было иметь с ним дело в эти моменты.

Несколько иного рода напряжение испытывал Михаил Степанович при общении с А.А. Громыко. Надо сказать, что Андрей Андреевич пользовался безграничным авторитетом у Капицы, не в последнюю очередь и потому, что глава ведомства не позволял даже высшим представителям партийного руководства вторгаться в сферу ответственности МИДа. Михаил Степанович был ярым патриотом министерства и с нескрываемым удовлетворением рассказывал, как министр осадил однажды влиятельного кандидата в члены Политбюро, секретаря ЦК Б.Н. Пономарева. Тот намеревался в ходе поездки в Вашингтон затронуть проблему ОСВ, на что министр отреагировал емкой фразой: этой сложной темой в стране владеют лишь три человека-Л.И. Брежнев, он, Громыко, и Г.М. Корниенко. Хотя Михаил Степанович был всегда по-хорошему уверен в своих силах и знаниях, однако к каждому предстоящему контакту с министром относился не без опаски с учетом известных особенностей характера Громыко, присущей ему сдержанности. Правда, и здесь временами осмеливался позволять себе то, о чем не могли и помыслить высокопоставленные коллеги по работе. Однажды Капица - случай относится ко второй половине 1970 гг. - поднялся от министра в ве-селом расположении духа. На время отсутствия шефа «на телефонах» в его рабочем кабинете оставался помощник.

- Я предполагал,- с порога начал делиться Капица,-что мы не сойдемся с министром по конкретному вопросу, а потому загодя подготовился к потенциально скользкому обороту событий. В ответ на подчеркнуто недоуменную реплику ми- 
нистра, так чье же в итоге мнение должно браться за основу, я,- продолжал Михаил Степанович,достал из кармана две монетки достоинством 5 (потяжелее) и 10 копеек и задал встречный вопрос: какая из двух, Андрей Андреевич, весит больше? Министр по инерции ответил:

- Конечно, пятак.

- «А чье мнение весит больше?» Мгновенно оценив шутку, министр за-улыбался. Напряжение было снято. Расстался со мной по-доброму,заключил Михаил Степанович.

Капица был лоялен министру, Громыко знал это и ценил.

Михаил Степанович увлеченно, без оглядки, отдавался главному делу жизни. 5 ноября 1971 г. он, заведующий сектором внешней политики КНР от-дела Г.В. Киреев и автор строк «подчищали хвосты» по работе перед прибли-жающейся годовщиной Октябрьской революции. В девятом часу вечера Капица поднялся из-за стола и сказал:

- Все, закругляемся. Едем ко мне домой отмечать день рождения. Сегодня стукнуло пятьдесят.

Мы с Генрихом Васильевичем переглянулись, одновременно польщенные и огорошенные. Вместо того чтобы праздновать юбилей в кругу близких и друзей, он сидит на службе да еще попростецки приглашает подчиненных к себе. Это было выше нашего понимания.

С постепенным оживлением советско-китайских отношений хлопот в от-деле значительно прибавилось. В 1972 г. из Пекина вернулся советник нашего посольства И.А. Рогачев, который распоряжением В.В. Кузнецова был назначен еще одним заместителем Капицы. Позже, во второй половине 80-х годов, Игорь Алексеевич сменит Капицу на посту заместителя министра иностранных дел СССР. Многие годы затем с великой пользой для страны работал в наиболее противоречивый период ее развития послом в Китае, сейчас-член Совета Федерации Федерального Собрания РФ.

В начале 1970 гг. состоялось решение о направлении опытных диплома-тов-китаеведов для работы в некоторых наших крупных посольствах и гене-ральных консульствах исключительно по китайской проблематике. Однажды вечером Капица пригласил меня к себе и сказал:

- Знаю, что тебя вызывали в Управление кадров и предложили должность в Генконсульстве в Сан-Франциско. Ты вправе рассчитывать на заманчивую командировку, но от нас собирается уезжать слишком много людей, что грозит оголением ряда участков отдела. В Сан-Франциско думаю рекомендовать Женю Бажанова, а тебя просил бы остаться поработать со мной. Даю время до утра для размышлений. Если завтра изъявишь желание отбыть, незамедлительно завизирую положительную характеристику, и вперед!

Не раздумывая, ответил, что остаюсь в Москве. Михаил Степанович как-то по-особенному тепло улыбнулся и сказал:

- Еще выпадет шанс побывать в Америке.
С этого момента наши отношения по его инициативе начали постепенно принимать не только более доверительный рабочий, но и неформальный личный характер, несмотря на внушительную, семнадцатилетнюю разницу в возрасте. Он все чаще стал принимать приглашение поужинать у меня. По его же сигналу на «огонек» нередко подъезжал мой добрый товарищ и давний приятель Михаила Степановича, бывший корреспондент «Правды» в Пекине В.М. Пасенчук-поразительно одаренный от природы и щедрой души человек, талантливый дипломат, герой известного фильма «Юнга Северного флота», девизом которого при любых обстоятельствах было: все хорошо! От него Михстеп, все присутствующие получали мощную энергетическую подпитку. Временами наведывались руководители китайского направления деятельности своих организаций Б.Т. Кулик, В.Ф. Мочульский. И не только они...

Подкупала манера общения Михаила Степановича с людьми. Дверь его кабинета практически всегда была приоткрыта, и сотрудники отдела в любой момент могли войти к нему с неотложным рабочим либо острым личным вопросом. Частыми гостями в дневные часы были и испытанные временем друзья: Герой Советского Союза, разведчик по военной специальности, председатель Союза советских писателей В.В. Карпов; убеленный сединами профессор А.С. Пекарский-живая кладезь знаний и достойный пример скрытого аристократизма, восхищавший Капицу; генерал Генштаба И.И. Моторин-с ним Михаил Степанович обсуждал текущую военно-политическую обстановку в мире. Выкраивал он время и для общения с уже утвердившимися в жизни сыном Александром и дочерью Ларисой. Наездами из родных Капице мест бывал в Москве его младший брат, который днями просиживал в кабинете и с которым у Михаила Степановича были самые трогательные отношения.

Особый разговор о рабочих контактах Капицы. Как заведующего отделом, его связывали тесные, основанные на взаимном профессиональном доверии, отношения со многими руководителями территориальных и общефункциональных подразделений министерства. Вспоминаются в первую очередь его отношения с заведующими отделом США Г.М.Корниенко, позднее В.Г. Комплектовым, заведующим II Дальневосточным отделом Н.Н. Соловьевым, заведующими отделом стран ЮВА С.С. Немчиной и И.А. Рогачевым, заведующим III Европейским отделом А.П. Бондаренко, начальником Историко-дипломатического управления академиком С.Л. Тихвинским. Михаил Степанович высоко отзывался о своих коллегах. Такой штрих: Капица трудится над текстом проекта документа, который перед уходом «наверх» должен быть завизирован им и заведующим отделом США. Закончив работу, говорит:

-Иди с папкой к Корниенко и внимательно вникай в смысл каждой воз-можной правки. У Георгия Марковича светлая голова и большое будущее. Па-шет как вол... 


\section{- Золотой фонд МГИМО}

Одновременно Капица умудрялся напряженно трудиться, естественно, в вечерние часы над книгами по современной политике Китая и обстановке в АТР. В 1960-1970 гг. вышли такие его книги «на злобу дня», как «Два десятилетия-две политики», «История международных отношений на Дальнем Востоке» (в соавторстве), «Три десятилетия-три политики» и совместная с Н.П. Малетиным работа «Сукарно. Политическая биография». Бережно храню экземпляры с дарственной надписью Михаила Степановича. Не счесть его выступлений под псевдонимом в средствах массовой информации, на радио. И это при сонме нескончаемых повседневных раздражителей и забот.

Выдающейся-других определений не подобрать- чертой неуемного ха-рактера Михаила Степановича являлась его готовность буквально в любое время суток прийти на выручку попавшим в беду то ли по собственной вине, то ли по стечению обстоятельств товарищам по службе, да и просто ранее неизвестным людям. Многократно был свидетелем таких широких жестов Михаила Степановича. Делал он это порою в обход, а при крайней необходимости даже в явное нарушение принятых тогда правил общественной игры, благодарно памятуя о жертвенной взаимопомощи односельчан в голодные годы, а также судьбоносной поддержке университетских друзей на заре жизни.

Так, Михаил Степанович внимательно следил за жизнью и бытом своей малой родины. По рассказам Цехони, в первой половине 1950 гг. Капице удалось с помощью настойчивых обращений к высокому руководству «пробить» разрешение на поставку в Юрковцы небольшой электростанции, крайне дефицитной по тем временам. Однако местные начальники порешили, что это будет «слишком жирно» для глухого угла и распорядились разместить станцию в районном центре. Михаил Степанович напрямую обратился к В.М. Молотову (в 1954 г., после четырехлетнего перерыва, вновь возглавившего МИД) за поддержкой в вопросе «не по существу». Молотов был крайне удивлен, недоволен, но все же среагировал, и тамошние деятели молниеносно были «поставлены на место». Однажды спросил у Михстепа, правильно ли живописует эту историю Иван Николаевич? Капица подтвердил, что все так и было.

Из ряда вон выходящий эпизод имел место во второй половине 1960 гг., когда я уже работал в МИДе. Знаю о нем не понаслышке. Михаил Степанович занимался тогда проблемами ЮгоВосточной Азии. Два молодых дипломата получили назначение на различные должности в нашем посольстве в Ханое. Время было суровое, во Вьетнаме шла война. Американские самолеты ежесуточно утюжили ковровыми бомбардировками землю многострадальной страны, и сборы в командировку проходили не в самом радужном настроении. Накануне отлета друзья устроили в ресторане прощальный ужин с вереницей тостов и, спускаясь после трапезы по улице Горького (ныне- Тверская) к Манежной площади, сподо- бились расколотить стекло одного из магазинов. Естественно, были задержаны бдительным постом самого близкого к Кремлю отделения милиции. Хмель выветрился из головы в считанные минуты. Бедолаги начали умолять возвратить им отобранные милиционерами загранпаспорта. На что дежурный майор неласково возразил: «Наломали дров- умейте и отвечать». Тогда горемыки, посовещавшись, попросили разрешения позвонить домой своему начальнику из МИДа, Капице.

- Это какому Капице,- встрепенулся майор,не тому ли, кто недавно чи-тал лекцию в нашем отделении. Интересней до этого и не было.

- Ему, ему,- с надеждой закивали наши герои. -Звоните. Ваше счастье, если снимет трубку. Шел второй час ночи.

Вскоре Капица был в отделении. Подробно объяснив майору, в каких ус-ловиях придется служить нарушителям порядка, Михаил Степанович стал уго-варивать его не только вернуть загранпаспорта, но и удалить фамилии молодых дипломатов из журнала записи происшествий. Майор согласился. Было оговорено, что и ремонт будет произведен за счет набедокуривших. Но что-то не сработало в слаженном милицейском механизме. Утренняя смена доложила начальству о ночном ЧП, и в МИД пришла бумага с просьбой принять должные меры к провинившимся. Дело обсуждалось на парткоме министерства, и Михаил Степанович получил очередное взыскание за отсутствие «принципиального подхода» к воспитательной работе.

Трагикомический эпизод имел продолжение. Путь в Ханой и обратно ле-жал тогда с промежуточной посадкой в Пекине. Сотрудники нашего посольства во Вьетнаме в ожидании авиарейса останавливались на пару дней для отдыха на территории посольства СССР в КНР. Естественно, крепко дружившие китаисты и вьетнамисты частенько делились насущными проблемами и переживаниями в те необычайно сложные для них годы работы. На очередной совместной «посиделке» в конце 1968 г. мы и узнали из уст одного из «счастливчиков» любопытные подробности. Вызволив нас, делился проезжий коллега, Михстеп в крайнем раздражении сказал:

- Мерзавцы, так и быть, вылетайте завтра в Ханой. Выручаю вас лишь потому, что придется работать под бомбами. Если история получит огласку, схлопочу «на орехи». Но, думаю, никто возвращать вас из Ханоя не станет. Не тот случай.

События и впрямь пошли по сценарию, предугаданному Михаилом Сте-пановичем.

-Лучше Капицы в министерстве человека нет,- расчувствовался гость. Под впечатлением от услышанного присутствовавшие, как один, одобрительно закивали головами.

В октябре 1973 г. я получил назначение в Токио. Наше посольство в Япо-нии возглавлял тогда давний знакомый Капицы, рассудительный и искусный дипломат О.А. Трояновский, впоследствии постпред при ООН и посол СССР в Китае. Однако Михаил Степанович отправил со мной ре- 
комендательное письмо не ему, а другу молодости И.Н. Цехоне, советнику-посланнику посольства.

- Учись у Цехони, он «большой дока» в японских делах, во всем следуй его наставлениям.

Прочитав с тщанием записку Капицы, Цехоня усмехнулся и сказал:

- «Ввинчивайся» на неделе в первые, самые поверхностные пласты мест-ной китайской проблематики, а вечером в пятницу возьму с собой за город со-прикоснуться уже с японской действительностью. Тебе повезло - поедем знакомиться с одним из известных японских философов современности. Вскоре наши отношения с Иваном Николаевичем переросли формальные рамки, что не без удовольствия воспринял Капица.

Регулярно, приезжая в отпуск и отбывая в Токио, заходил к Михаилу Степановичу для доклада и получения указаний. В целом работа не вызывала нареканий. Но, придя в очередной раз, в сентябре 1976 г., попрощаться, неожиданно услышал:

-Твоя, старик, командировка в Японию приостанавливается. Распоряжение представителей КГБ. В чем загвоздка, пока сам не в курсе. Зайди через неделю.

На следующей встрече с места в карьер:

- Тебя обвиняют в том, что слишком тесно якшался с американцами и за-думал, мол, самое страшное... Было дело?

- Как отцу говорю, нет и в помине!

- Точно?

- Точно!

С этого момента я уже, что называется, на собственном примере прочувствовал, как яростно и последовательно умеет драться Михаил Степанович за людей, как глубоко живет в нем чувство неприятия любой несправедливости. Он взял меня за руку и приказал: идем к Трояновскому. Кабинет Олега Александровича как заведующего II ДВО располагался напротив рабочей комнаты Михстепа. Постучавшись и войдя со мной в кабинет к Трояновскому, Капица утвердительно сказал:

- Олег, ты в курсе претензий КГБ к Грешных. Чепуха какая-то. Прошу, поручись за него.

Трояновский, однако, предпочел уклониться, сославшись на то, что вопросы ко мне возниклиде уже через 3 месяца после его отъезда из Токио, при после Д.С. Полянском.

Капица побагровел. Возвратившись к себе в кабинет, поразмыслив, он набрал по спецсвязи номер телефона представителя КГБ в МИДе генерала М.И. Курышева:

-Я по поводу Грешных.

- Ему не работать в МИДе. Пусть пишет заявление об уходе из министерства по собственному желанию,- отреагировал Курышев.

- В таком случае начинайте с меня. Именно я рекомендовал его на работу в Токио.

-Михаил Степанович, так нельзя ставить вопрос. Речь о Грешных.

- Я верю ему, а не вашим информаторам. Буду отстаивать его до конца,-заключил Капица и положил трубку.
- Отправляйся домой, попробуй успокоиться и заснуть,- посоветовал Михаил Степанович. Завтра до начала рабочего дня будь у меня.

Сон, разумеется, не шел. В районе 8 часов вечера в прихожей раздались веселые голоса. Войдя в спальню, жена сказала:

- Ты посмотри, кто к нам приехал!

В коридоре стоял, молча улыбаясь, В.В. Шарапов, помощник Ю.В. Андропова, китаевед по профессии. Мы с женой познакомились с ним еще до командировки в Японию. Виктор Васильевич сказал, что понадобится время для прояснения ситуации. Выпив чашку чая и подбодрив, он возвратился на работу.

Наутро Капица с загадочной миной на лице поинтересовался, был ли у меня кто-нибудь в гостях накануне. По телу прошла волна безмерной благодарности. Понял, приезд В.В. Шарапова-результат действий Михстепа в мою поддержку по всем возможным направлениям.

Через несколько дней Михаил Степанович провел со мной обстоятельную беседу:

- Из МИДа пока не уволят. На время расследования лишат доступа к сек-ретной переписке и возможности выезда за границу. Если даже все закончится благополучно, считай, что у тебя будет украдено 5-7 лет служебного роста. Набирайся терпения. Отныне станешь исполнять обязанности помощника по научным вопросам. Как председатель ВАК «зашиваюсь» с рецензиями на докторские диссертации. Вот и займись этим на первых порах.

Пятилетняя работа в новом качестве дала благодаря заботливому реше-нию Капицы уникальную возможность расширить представление об истории и содержании современных взаимоотношений государств различных регионов мира.

Михаил Степанович спас меня и семью от неминуемой, казалось, жизненной катастрофы. Кто знает и помнит о реалиях того времени, согласится со мной. Я продолжал заниматься любимым делом. Капица демонстративно наведывался ко мне домой, оказывая неоценимую моральную поддержку.

Знаю определенно, что на самого Михаила Степановича не раз приходили в «органы» и в ЦК партии подметные письма с требованиями разобраться в его политических взглядах, особенно после некоторых закрытых выступлений. Одним из известных мне примеров может служить отвратительная кляуза по поводу изложенной им в лекции истории формирования границ между Российской и Китайской империями. Но были и куда более серьезные и гадкие «сигналы». Приходилось отбиваться во властных кабинетах. Михстеп никогда не делился подробностями периодических-крупных либо мелких-неприятностей. Но они отнимали у него драгоценное время, небезграничные силы и, чувствовалось, годы жизни.

Конец 1970- начало 1980 гг. стали этапными для Михаила Степановича с точки зрения качественного упрочения его позиций на дипломатическом и научном поприщах. То был период 


\section{- Золотой фонд МГИМО}

общего серьезного обострения международной обстановки и новых трудностей в советско-китайских отношениях. Особенно сложным оказался 1979 г.: в феврале-марте разразилась война между КНР и СРВ; в апреле китайская сторона заявила о непродлении Договора о дружбе, союзе и взаимной помощи между КНР и СССР от 14 февраля 1950 г.; в декабре начался ввод ограниченного контингента советских войск на территорию Афганистана, несколько наших танков на короткий срок появились даже в одном из районов афганокитайской границы.

Возрос накал двусторонней полемики. Министр посвящал много времени китайской проблематике: участились вызовы Капицы на 7-й этаж. Лавинообразно увеличивалось количество входящих в отдел, а главное, исходящих бумаг. Если раньше 12-часовой режим работы был для Михаила Степановича исключением, то теперь стал почти регулярным явлением. А в коридоре перед кабинетом скапливались просители, жаждущие получить помощь Капицы в различных вопросах: от защиты диссертации до решения сугубо бытовых проблем. Таких за месяц набиралось несколько десятков. Он не отказывал никому. Трудно понять, как Михаилу Степановичу удавалось переносить сумасшедшие перегрузки. Со стороны же казалось, что со всем он справляется легко, внешне играючи.

Капица вдохновенно и красиво работал за столом. Покидая же кабинет, неизменно оказывался в центре внимания со своим веселым нравом и общительным характером. Сопровождал Михаила Степановича на многочисленные встречи и свидетельствую: он был буквально нарасхват в дипкорпусе. Число связей не поддавалось учету.

Отдельная тема-контакты, «техника» работы Капицы с китайскими ди-пломатами, будь то в Москве или Пекине. Михаил Степанович не только хорошо знал, понимал, но и всем своим существом любил столь дорогой его сердцу Восток. Китайцы интуитивно чувствовали это и воспринимали с внутренней благодарностью. Даже в самых крайних обстоятельствах Михаил Степанович умудрялся сохранять и поддерживать с китайскими представителями отношения взаимного уважения и своеобразного доверия. Инструментарий Капицы был велик, но он крайне редко прибегал в переговорном процессе к действиям на «грани фола», притом исключительно в интересах дела, для защиты принципиальной политической позиции. Он тонко ощущал, молниеносно схватывал особенности склада характера партнера по беседе либо по переговорам и безошибочно вычислял его вероятную реакцию на ту или иную ситуацию. После вручения зарубежному коллеге официального представления по какомулибо неприятному поводу( а такое случалось в контактах не только с представителями КНР, но порою и КНДР) Михаил Степанович неизменно пытался несколькими нейтральными репликами предельно сгладить неизбежно возникавшую напряженную атмосферу-«ничего личного». Он провожал каждого посла до лифта, хотя это и не пре-дусматривалось протокольными условностями или сложившейся практикой.

Китайские дипломаты платили той же монетой. Капица изначально вызывал у них жгучий, в чем-то даже болезненный, не проходящий интерес. На мероприятиях в посольстве КНР, после завершения неизбежной беседы с послом по текущим вопросам и демонстрации знаков внимания и расположения к его супруге Михаил Степанович моментально оказывался в окружении более молодых сотрудников представительства. Подтягивались и наши начинающие дипломаты. Образовывалась на время небольшая компания, в которой каждый чувствовал себя раскованно и комфортно. Хозяева забрасывали Капицу просьбами поведать о своей работе в Чунцине и Нанкине в 1940 гг., впечатлениях о встречах с будущими руководителями КНР, его оценках текущих событий на международной арене, причем не всегда в привязке к Востоку. Капица охотно отвечал, иногда рассказывал свежую «байку». Стороны были довольны друг другом. Атмосфера напряженности в двусторонних отношениях оставалась как бы за «кадром».

Шел 1981 г. Перед очередным приемом в китайском посольстве Капица заметил:

- Прошло достаточно много времени с тех пор, как вроде бы к тебе пере-стали предъявлять претензии. Хорошо бы прояснить ситуацию, но в лоб это де-лать нежелательно. Есть задумка...

Вечером, Капица при мне обратился к послу Ван Юпину:

- Помощник до сих пор мыслит категориями времен «культурной рево-люции», хотя ситуация в Китае меняется на глазах. Какой из него советчик? Нельзя ли получить приглашение из МИД КНР, пусть совершит ознакомитель-ную поездку по стране, почистит мозги?!

Ван Юпин, с которым у Михаила Степановича наладились добрые рабочие отношения, ответил, что проблем возникнуть не должно, поскольку это личная просьба Капицы. Вскоре я колесил по просторам северо-востока Китая, заехал и в наше посольство в Пекине. Капица был доволен.

- Благодари китайцев,- сказал он,- при их опосредованной поддержке сделан первый шажок вперед. Посмотрим, что будет дальше...

Подвижнический, без натяжки, труд Капицы, его преданность делу, высочайшая квалификация были наконец вознаграждены. В декабре 1982 г. Михаил Степанович был назначен заместителем министра иностранных дел СССР, отвечающим за сложный комплекс проблем наших взаимоотношений со странами АТР. Несколько ранее, в начале сентября, я перешел на работу в УПВМ. События не повлияли на характер наших личных взаимоотношений, но видеться стали мы реже.

Формально управление возглавлял заместитель министра А.Г. Ковалев, но на деле тяжеленный воз обязанностей тянул на своих плечах его заместитель А.М. Белоногов. По ходатайству И.Н. Цехони, заведующего отделом Азии, я был 
утвержден Белоноговым старшим советником подразделения. Александр Михайлович был в курсе претензий КГБ ко мне, это было неприятно, однако своим волевым решением он все же откликнулся на рекомендацию Ивана Николаевича. Через несколько лет смелый поступок Белоногова круто изменит мою жизнь и направление работы. В небольшом по численности управлении трудилась группа маститых специалистов по самым разнообразным вопросам; работал и сын Ю.В. Андропова, Игорь Юрьевич, впоследствии посол в Греции. Дел хватало. В органически свойственной ему деликатной манере Александр Михайлович молчаливо поощрял мои периодические вылазки в кабинет Капицы, от которого я, разумеется, возвращался с набором нетривиальных идей и имеющих реальную пер-спективу соображений. Встречал Михаил Степанович радушно, начиная обычно разговор не со служебных новостей. Сетовал, что после перемещения на «командный», 7 этаж, круг общения с хорошо знакомыми коллегами заметно сузился.

В конце октября 1983 г. раздался звонок Капицы.

-Хватит протирать штаны в управлении и витать в эмпириях,- начал под-трунивать он. Полезно хоть раз в году предпринять попытку совместить красоту высоких теорий с печалями приземленной практики. Решил дать несколько дней отдыха своему помощнику. Полетишь со мной сопровождающим в Монголию. Да и лишний выезд из страны в твоем положении не помешает. Отпросись у Александра Михайловича.

Через несколько дней прибыли в Улан-Батор. Исполнив поручение нашего руководства в приватной беседе с главой МНР Ю. Цеденбалом, с которым у Капицы издавна сложились самые добрые отношения, он по приглашению монгольской стороны отправился на Халхин-Гол. Летела наша небольшая группа на личном АН-24 министра иностранных дел М. Дугэрсурэна, кстати, питомца МГИМО первого послевоенного выпуска, верного друга нашей страны. И здесь представился случай познакомиться с еще одной, сугубо мужской чертой характера Капицы-хладнокровием. Взглянув в иллюминатор, Михаил Степанович вслух заметил, что один из моторов остановился.

-Решение за тобой, Мангалын. Может, вернемся в Улан-Батор? на ЧП:

Дугэрсурэн призвал не обращать внимания

-При крайней надобности сядем в степи. Уже приходилось.

Капица лишь усмехнулся и принялся неторопливо накрывать ноги пледом. В Чойбалсане двигатель починили, и в сумерках мы приземлились рядом с монгольской пограничной заставой. Покинув самолет и сделав несколько десятков шагов, Капица остановился как вкопанный. Он с недоумением рассматривал невысокий каменный столбик белого цвета с тремя отчетливыми иероглифами-«маньчжоуго» (маньчжурское государство). В условиях еще не преодоленной скрытой напряженности вдоль советско-китайской и монголо-китайской границ, это выглядело, по меньшей мере, необычно.

- Как погранзнак, обозначающий линию двусторонней границы начала века, мог оказаться в глубине монгольской территории?- не без тревожных ноток спросил Капица.

Дугэрсурэн ответил, что теперь линия монголо-китайской границы реально проходит на несколько сотен метров впереди.

- Она на рубежах, куда вышли танкисты бригады Яковлева и монгольские цирики в боях с японскими агрессорами. Китайская сторона знает о существовании погранзнака, равно как и о прежней линии прохождения границы, но, не желая терять лицо, даже не касается этого вопро$\mathrm{ca},-$ заявил он.

Капица покачал головой...

Провели два дня на территории заставы. Михаил Степанович при живом участии Дугэрсурэна задушевно, по-домашнему пообщался с представителями аймачных властей, много и к месту шутил. Внимательно осмотрел блиндаж Г.К. Жукова, находившийся в идеальном состоянии благодаря заботам друзей. Несколько километров проехал по берегу реки вдоль линии безлюдной границы. Выбрался с хозяевами на охоту. Перед отлетом заботливо, без нажима, порекомендовал Дугэрсурэну не упускать из виду небольшой пограничный камень, дабы, не приведи Господь, он не превратился при определенных обстоятельствах в «камень преткновения».

Не раз был свидетелем того, как в контактах с дипломатами азиатских государств он безошибочно вычленял потенциально наиболее взрывоопасные точки взаимоотношений и старался, действуя на опережение, погасить в общих интересах развитие неблагоприятных тенденций, по возможности в самом зародыше. Другой вопрос: как часто это удавалось? Мироощущение сынов Азии - тонкая материя. Их восприятие бесконечного течения реки времени зачастую недоступно пониманию европейцев. И Михаил Степанович при рассмотрении будь то застарелых проблем, либо вновь возникших противоречий всегда умел мастерски учитывать исторически сложившиеся особенности мышления и стереотипы поведения представителей стран Востока. Это было характерной чертой Михаила Степановича как признанного специалиста и многоопытного дипломата государственного масштаба.

После доклада министру о политических результатах поездки в Монголию Михаил Степанович преподнес ему собственноручно добытую шкуру громадного степного волка. В этом знаке внимания не было и намека на подобострастие ближайшее окружение А.А. Громыко хорошо знало, что министр сам постепенно пристрастился к охоте под влиянием азартного в этом деле Л.И. Брежнева.

Осенью 1984 г. А.М. Белоногов был назначен послом СССР в Египте. За-собирались в командировку и ряд сотрудников управления. Зашел 
разговор о моем возможном выезде в Таиланд советником-посланником нашего посольства. Инициатива управления кадров была пресечена Михаилом Степановичем.

- В Бангкок не поедешь. Отправишься в посольство в Китае на должность советниказаведующего консульским отделом,-заявил он.

На мое осторожное замечание, что я не знаю консульской работы и что это чревато незаслуженным понижением по службе, заместитель министра отрезал:

- Я тебя в свое время выручил. Теперь очередь за тобой. Так складывается ситуация, что ты мне нужен в Пекине, и именно на месте консула.

В который уже раз решение Капицы благотворно сказалось на моем кругозоре и делах. Благодаря открывшимся возможностям посчастливилось побывать во многих уголках Китая, даже совершить вместе с Е.П. Бажановым - с молчаливого согласия китайских властей-немыслимую до тех пор частную поездку по провинциям восточного побережья Китая и на о. Хайнань.

Радостными и вдохновляющими моментами в жизни наших дипломатов были приезды Михаила Степановича в Пекин для встреч и бесед с высокопо-ставленными китайскими представителями. Ритм работы посольства убыстрялся. Дипломатия, говаривал Капица, труд коллективный. При сохранении разногласий по многим вопросам двусторонних отношений и международной политики с какого-то момента начал исподволь ощущаться и постоянно крепнуть ветерок надежды, грядущих перемен к лучшему. В ноябре 1984 г. по предложению советской стороны было подписано консульское соглашение. Активировался переговорный процесс, оживали контакты по другим линиям, рос товарооборот.

Свою длань к позитивным сдвигам приложил и Капица. Работа Михаила Степановича на посту заместителя министра иностранных дел СССР была зенитом его профессиональной деятельности. Он по праву занимал самое высокое для наших дипломатов-востоковедов карьерное положение. Это не подлежало сомнению. Подоспело и своеобразное, но авторитетное подтверждение. Зимой 1985 г. мне позвонил посол И.С. Щербаков и сказал, что в Пекин на несколько дней приехал С.Л. Тихвинский. Напомнив, что Сергей Леонидович был Генконсулом СССР в Пекине еще в 1945 г., посол резюмировал:

- Тебе как консулу и карты в руки. Прими Тихвинского порадушней, обогрей.

Пригласил Сергея Леонидовича к себе домой. В ближайший выходной всей компанией-гость, жена Нина, дочь Наташа и я, - отправились по просьбе Сергея Леонидовича в дальний пригород Пекина Сяншань («Душистые горы»). После длительной прогулки по бодрящему морозцу мэтр пребывал в добром расположении духа, с охотой отвечал за обедом на наши вопросы о друзьях-товарищах по работе в Китае в 40-е г.г. Сухая запись из блокнота: Федоренко-книгочей, эрудит; Иваненко (Василий Иванович работал в 1940-1943 гг. в Синьцзяне)-надежный, жизнерадостный парень. О Капице: М.С. выделялся всегда, уникальная фигура.

С 1987 г. мои контакты с Михаилом Степановичем стали носить спорадический характер. За год до этого А.М. Белоногов был назначен постпредом СССР при ООН. По его настоянию и с санкции завотделом международных кадров ЦК партии С.В. Червоненко мое «дело» было наконец закрыто, и я напрямую, по инициативе Александра Михайловича, был переведен из Пекина в Нью-Йорк. Торжеству Капицы не было границ.

- Увесистее пощечины зачинщикам «дела» и придумать нельзя. Едешь-таки в страну, куда якобы хотел удрать.

Он радовался, казалось, едва ли не больше меня. Сбылось его предсказание пятнадцатилетней давности, что мне еще придется побывать в США. Там проработал на разных участках, с небольшим перерывом, 7 насыщенных неординарными событиями лет под началом А.М. Белоногова, а затем Ю.М. Воронцова, в том числе в 1993-1994 гг., по личной договоренности Юлия Михайловича, с президентом Э.Ш. Рахмоновым на должности заместителя постпреда Таджикистана при ООН. Капица внимательно следил за моими делами, иногда перезванивались.

Приход в МИД в 1985 г. Э.А. Шеварднадзе обернулся для заслуженных дипломатических кадров крупными неприятностями. Новый министр ревниво относился к их опыту и знаниям. У Шеварднадзе не складывались отношения с А.Ф. Добрыниным, после возвращения из США назначенного заведующим международным отделом ЦК партии. Гонениям в той или иной степени подверглись Ю.М. Воронцов, Г.М. Корниенко, М.С. Капица и ряд других выдающихся специалистов старой школы.

С 1987 по 1994 г. Михаил Степанович работал директором Института Востоковедения. Его деятельность на этом посту - отдельный сюжет, который вправе освещать лишь те, кому довелось трудиться рядом с ним в это время. Знаю одно: в сложный, полный парадоксов, политических и экономических неурядиц период жизни страны Михаил Степанович оставался верен сформировавшимся мировоззренческим установкам, идеалам дружбы и взаимовыручки. Мало кто умел сопереживать так, как он. Именно в возглавляемом им институте с 1989 г. работал главным специалистом давний коллега по дипломатической службе Г.М. Корниенко.

Неоднократно бывал у Михаила Степановича, приезжая в отпуск из Нью-Йорка. Подолгу беседовали, благо, теперь у него появилось относительно больше свободного времени. Вкус и тяга к научной работе не оставляли Михстепа, но чувствовалось, что ему явно недостает активной политической и дипломатической деятельности, привычного интеллектуального и физического напряжения. 
Михаил Степанович тяжело воспринял распад многонационального, некогда могучего единого государства. Как великий патриот, он мучительно переживал откат страны от прочных, казалось бы, позиций, обретенных при жизни его поколения. С окончанием «холодной войны», констатировал он, внешний мир не стал благожелательнее относиться к России. Михаила Степановича беспокоило ослабление пояса безопасности государства, ощутимое ослабление его геополитического положения. Капица называл отношения со странами СНГ приоритетными для России, а территорию Содружества-зоной ее жизненных интересов. Мысля стратегическими категориями, Михаил Степанович видел утверждение России на мировой арене в качестве великой державы на путях постепенного восстановления сотрудничества на пространстве СНГ и укрепления многоформатных связей с Китаем, Индией, Вьетнамом, другими ведущими странами Востока. Еще в 1994 г. он высказывал идею создания организации евразийского сотрудничества, которая в наши дни обретает новое дыхание.

Мысль Капицы пульсировала мощно и безостановочно. Размышляя, пом-нится, о будущем взаимоотношений России с Западом и Востоком, Капица исходил из того, что Вашингтон вряд ли когда-нибудь станет рассматривать нас как партнеров, а тем паче союзников. Где всерьез и надолго могут совпадать интересы США и России, полагал Михаил Степанович, так это нераспространение ядерного оружия, а также обостряющиеся проблемы защиты окружающей среды. В отношениях же России и Западной Европы дополнительным скрепляющим элементом будет служить встречный экономический интерес. В остальном, считал он, «большой Запад» будет стараться под разными предлогами всячески ограничивать новую Россию в ее маневре как на глобальном, так и региональном уровнях.

Иное дело, «большой Восток». Капица на излете XX столетия с убеждением говорил о том, что серьезное осложнение советско-китайских отношений в 1960 - первой половине 1980 гг.- трагический зигзаг в истории их современных взаимосвязей, в котором повинны обе стороны. Развитие и укрепление сотрудничества между Россией с ее богатыми природными и интеллектуальными ресурсами и Китаем с его людскими и растущими экономическими возможностями пойдет на пользу не только двум великим державам, но и, утверждал он, послужит мощным фактором стабилизации всей международной обстановки. Отталкиваясь от своего богатого опыта общения с представителями мусульманских государств, Михаил Степанович называл еще одной крупной внешнеполитической задачей страны восстановление и развитие партнерских связей с исламским миром, прежде всего с арабскими государствами и Ираном.

Строго говоря, констатировал Капица, жизненно необходим непрекра-щающийся поиск возможно более точного баланса в отношениях как с Западом, так и Востоком в национальных интере- сах новой России. Он не принимал «дипломатию А.В. Козырева» с ее явно выраженным креном в сторону Запада.

В любой ситуации Капица старался не просто определить, выделить государственный интерес страны, но и реализовать его применительно к конкретным, зачастую не самым благоприятным, политическим условиям. Он смотрел вперед без пессимизма, здраво анализируя и реально оценивая складывающуюся в стране и вокруг нее обстановку. Оценивая с позиций блистательного дипломата и политика. Стратега. Патриота.

Капица в беседах неизменно возвращался к годам работы в МИДе, трога-тельно вспоминал бывших коллег и подчиненных. Особенно тепло отзывался о послах в Китае В.С. Толстикове и И.С. Щербакове; дипломатах-востоковедах М.И. Басманове, Б.Н. Верещагине, А.И. Елизаветине, Ф.И. Потапенко, Л.А. Кубасове, Р.Ш. Кудашеве, Д.А. Байдильдине, Н.С.Крюкове, Г.А. Звереве, И.В. Григорове, Ю.А. Королеве и многих других.

Михаил Степанович раньше времени ушел из жизни. В силу привходящих, прежде всего исторических обстоятельств - слома эпох, ему не удалось реализовать львиной доли способностей и таланта, щедрой горстью отпущенных природой. Проводить его пришли десятки людей, в чьих жизнях он оставил свой, неподвластный забвению, след. Присутствовали послы всех азиатских государств, аккредитованных в Москве. Соболезнования прислал даже резидент американской разведки в Китае в 1946 г.-член миссии США при правительстве Чан Кайши в Нанкине.

Глубоко ранящая утрата коснулась не только востоковедческой семьи. Как-то на одном из рейсов самолета Москва-Нью-Йорк оказались рядом места А.Ф. Добрынина и дочери М.С. Капицы. Разговор зашел о Михаиле Степановиче.

- Я любил и ценил Михаила Степановича,- заключил Анатолий Федоро-вич.

- Отец тоже очень любил вас,- сказала Лариса Михайловна.

Эти строки-дань сердца бесконечно близкому человеку. Михаил Степанович был необыкновенной, искрящейся оптимизмом, солнечной личностью. О широте его натуры ходили легенды. Именно таким запомнился он друзьям, товарищам по работе, коллегам по научным делам.

Низкий поклон!

Светлая и благодарная память!

Valery K. Greshnykh. Unforgettable "Michstep".

Summary: The article represents personal recollections about an outstanding Soviet dip-lomat and orientalist Kapitsa Michail Stepanovich, who left a noticeable imprint on the history of relationship between USSR and China, India, Pakistan, Indonesia and other countries of Asian-Pacific region. Being the author of numerous research stu-dies, brilliant lecturer and charismatic personality, Kapitsa exercised a significant influence on the formation of Soviet diplomatic cadres and Orientalists. Kapitsa M. S. has been rightly reputed as one of the best experts on problems of the Asian Pacific Rim both in the USSR and abroad. 